\title{
КОМПОЗИЦІЙНИЙ ВПЛИВ КАМЕРНІЗАЦІЇ ЯК ОДИН З ФАКТОРІВ СТАНОВЛЕННЯ ДРАМАТУРГІЧНОГО ПРОЦЕСУ У КОНЦЕРТНИХ ТВОРАХ ДЛЯ ФОРТЕПІАНО 3 ОРКЕСТРОМ ХХ СТОРІЧЧЯ
}

\author{
Решетілов Б. Н., аспірант \\ Украӥна м. Київ Національна музична академія Украӥни імені П. I. Чайковського
}

DOI: https://doi.org/ 10.31435/rsglobal_ws/30122018/6277

\section{ARTICLE INFO \\ Received: 23 October 2018 \\ Accepted: 27 December 2018 \\ Published: 30 December 2018}

\section{KEYWORDS}

Chamber nature, dramaturgy formation, piano with orchestra.

\begin{abstract}
The subject of this research is to consider the compositional properties of the chamber tendency in relation to drama in compositions for solo instruments within a chamber orchestra. As twentieth century composers' raised interest in chamber-orchestral concert genres, this caused a number of consequences affecting the formation of dramatic specifics. Some of these include those trends of chamber tendency, which relate to timbre, form, genre, neoclassical manifestations, aesthetics, character directivity, etc. Revision of the semantic component of the chamber orchestra toolkit can appear as a movement towards single-timbre or an emphatic ensemble style. Neoclassical trends through the prism of chamber tendency influence the semantic content of character spheres. Keeping and development of chamber-instrumental music traditions create a special kind of musical material presentation, manifested in the deepening of the sphere of individualization and characterization of a subject. Genre orientation, addressed to the rebirth of the main achievements of past epochs, affects not only the semantic load of character spheres, but also a drama in general. Overall miniaturization as one of tendencies of the twentieth century in the context of the chamber nature leaves its trace in formation of character spheres as a tendency to concentration or continuity. Thus, in general, in the concert genre of the twentieth century the specific innovation patterns are created in the formation of conceptual intonation of character dramaturgy.
\end{abstract}

Citation: Решетілов Б. Ю. (2018) Kompozytsiinyi Vplyv Kamernizatsii yak Odyn z Faktoriv Stanovlennia Dramaturhichnoho Protsesu u Kontsertnykh Tvorakh dlia Fortepiano z Orkestrom XX Storichchia. World Science. 12(40), Vol.2. doi: 10.31435/rsglobal_ws/30122018/6277

Copyright: (C) 2018 Решетілов Б. Ю. This is an open-access article distributed under the terms of the Creative Commons Attribution License (CC BY). The use, distribution or reproduction in other forums is permitted, provided the original author(s) or licensor are credited and that the original publication in this journal is cited, in accordance with accepted academic practice. No use, distribution or reproduction is permitted which does not comply with these terms.

Вступ. Вже понад чотирьох віків існує жанр камерний концерт. Внаслідок інтенсивної інтеграції музики для фортепіано з камерним оркестром в мистецьку панораму XX сторіччя виокремлюються характерні властивості притаманні камерній музиці. Окремі аспекти цього феномену в контексті музики таких композиторів епохи бароко, як А. Кореллі, А. Вівальді та I. С. Бах розкрили дослідники М. Пеншерль, К. Кузнєцов, І. Ямпольський, В. Кольнедер, Г. Маліп’єро, Б. Доброхотов, І. Форкель, А. Швейцер. Жанровим зрізом загалом оркестрової та концертової музики в контексті життя і творчості Й. Гайдна, В. Моцарта, Ф. Шуберта, Й. Брамса, Й. Штрауса, А. Дворжака, К. Сен-Санса, Р. Штрауса, А. Шенберга, Б. Бартока, I. Стравінського, П. Гіндеміта займалися науковці Л. Новак, Г. Аберт, Г. Гольдшмідт, П. Гульке, Ю. Хохлова, К. Гейрінгер, Є. Мейліх, 3. Тулінська, Ю. Крємльов, І. Хардінг, 
Е. Краузе, Т. Адорно, М. Друскін, Е. Кетлі, Е. Фрейтаг, І. Нест’єв, Т. Лєвая та інші [6]. В деяких аспектах камерну оркестрову музику XX сторіччя було висвітлено такими роботами, як докторська дисертація Л. Повзун «Камерність як жанрово-стильова парадигма інструментально-ансамблевої творчості» [5], кандидатська дисертація М. Басок «Сучасна камерна опера. До проблеми специфіки жанру» [3], кандидатська дисертація Н.Ксенофотнової «Камерний оркестр першої половини XX сторіччя (до проблеми історичної типології оркестрового письма)», нарис I. Барсової щодо камерної творчості П. Гіндеміта, стаття О.Сєдєльнікової про камерну симфонію 1960-х років тощо. Але першою узагальнюючою спробою охопити всю музику для камерного оркестру з точки зору генезиса, втілення традицій та виконавської інтерпретації належить Е. Прейсману (докторська дисертація «Камерний оркестр як явище в музичній культурі XVII-XX сторічь») [6]. Слід зауважити, що камерність не розглядалася в контексті трактовки правил відносно усвідомлення семантичних векторів драматургії. Це важливий аспект, в якому закладені аналітичні передумови драматургічної процесуальності. Відповідно, мета даної статті - простежити вплив камерності як загальної тенденції у становленні драматургії творів для фортепіано з камерним оркестром.

Основний текст. У XX сторіччі відбувається посилення цікавості композиторів до камернізації оркестрової музики. Це було викликано кількома причинами. Однією з них стає реакція на штампи та трафарети «великої симфонії» [2]. Симфонічний оркестр значно зменшується в нетипові склади виконавців. Внаслідок цього відсікаються певні оркестрові групи та видозмінюються тембральні засоби виразності. Саме таке обмеження партитурної палітри нівелює традиційне для симфонічного оркестру поєднання інструментів оркестру. Прослідковуються дві категорії тенденцій - доцентрова та відцентрова. Відтак концентрування може відбуватися всього на одній оркестровій групі (наприклад, Концерт для фортепіано, духового оркестру, літавр та контрабасу І. Стравінського 1924p., Камерна музика для фортепіано та 12 солюючих інструментів П. Гіндеміта 1924p., «Концертна музика» для фортепіано, мідних духових та двох арф П. Гіндеміта 1930p., Камерний концерт для скрипки, струнних, фортепіано та ударних Б.Мартіну 1941p., Концерт для підготовленного фортепіано та камерного оркестру Д. Кейджа 1951p., «Quodlibet» Концерт для фортепіано та камерного оркестру Н.Кастільйоні 1976p., Концерт для фортепіано та струнних А.Шнітке 1979р.) або на підкресленій ансамблевості 3 виокремленням солюючих інструментів (наприклад, Камерний концерт для фортепіано, скрипки та 13 духових А.Берга 1925р., Камерна симфонія для 12 інструментів Д.Енеску 1954p., Подвійний концерт для клавесина, фортепіано 3 двома камерними оркестрами Е.К.Картера 1961p., Камерний концерт для 13 інструментів Д. Лігеті 1970p., «...quasi una fantasia...» для фортепіано та двох камерних ансамблів Д. Куртага 1988p., Подвійний концерт для фортепіано, віолончелі та двох камерних ансамблів Д. Куртага 1990p., «Intarsi» Камерний концерт пам'яті В.Лютославського для фортепіано і ансамбля К. Хубера 1994р.,).

В першому випадку відбувається пошук нових засобів виразності в межах оркестрової однотембральності. 3 цього витікає певна образна континуальність, так як інструментальна однорідність формує монолітне тембросприйняття. Внаслідок цього загострюється темброве розмежування образних сфер. Твори для сольних інструментів 3 однорідним камерним оркестром характеризуються подібними шляхами розвитку, в яких аналіз драматургічної процесуальності відштовхується від фіксації конкретної кількості превалюючих тембрів, що мають формотворчу властивість стосовно становлення образних сфер. В результаті відбувається посилення протиставлень образних сфер масивної направленості та зменшенокамернізованої. Наприклад, цікавої тембрової функціональності набуває Камерна музика для фортепіано та 12 солюючих інструментів П.Гіндеміта. 3 однієї сторони, склад оркестру передбачає групу солістів. 3 другої - від самого початку до кінця майже неможливо знайти хоч одну мелодію в партії оркестру без дублювання. Тобто підхід, по суті, до ансамблевої структури відбувається виключно оркестровими методами та мікстами. Це дає підстави в даному випадку трактувати роль оркестру в якості цільного чинника образної сфери.

В другому випадку відхід у сторону ансамблевості значно зменшує використання прийому дублювання партій інструментів. Така сольно-тембральна рясність дає поштовх до трактування драматургічних образів у сфері руху та постійного видозмінення. Внаслідок мінімізації масово-оркестрових можливостей відбувається тенденція до економії та ретельної деталізації ритмічних, інтонаційних, динамічних засобів виразності тощо. Наприклад, це проявляється в камерному концерті для 13 інструментів Д.Лігеті, де підхід до формування партії кожного інструменту відбувається шляхом індивідуалізації та значного ускладнення 
виразності в цілому. Це відкриває нові можливості персоніфікації та характеристики, що може значно збільшувати багаторівневу наповненість драматурічної процесуальності образністю.

Наступною властивістю камернізації стає посилення інтересу до музики минулих епох, зокрема античності, середньовіччя, бароко та класицизму. Відлік усвідомлення цього явища як самостійної стильової течії в західноєвропейській музичній думці прийнято вести з відкритого послання Ф. Бузоні П. Беккеру, опублікованого на початку 1920p. під назвою «Новий класицизм?». Вже з 1923p. (час появи «Октету для духових» І.Стравінського) усвідомлення цієї тенденції закріплюється в музичному просторі під назвою неокласицизм, який починає самостійне життя у вигляді художньо-стильового музичного напрямку [7]. Це спричинило жанрові, стильові, інструментальні та естетичні зміни. Відбувається переродження музичних жанрів минулих епох (партити, concerto grosso, сюїти тощо). Семантичне співіснування різних жанрових першооснов обумовлює подальшу естетичну та функціональну амбівалентність камерних інструментально-ансамблевих жанрів [4]. Наприклад, Concerto grosso для камерного оркестру Б.Мартіну витримане в ключових традиціях жанру. Відповідне звертання до жанру має формотворчу функціональність не тільки у плоскості композиційної структури. Драматургічна процесуальність в таких випадках може напряму підпорядковуватися обраним установкам відносно жанрових особливостей. Ретроспективна забарвленість стилістики образних сфер нерідко переходить у бік проблематики взаємодії минулого та сучасного. Наприклад, у Concerto grosso № 1 А. Шнітке такі діалогічні протиставлення формують логіку драматургічних зв'язків у тих плоскостях, домінуючою характеристикою яких є звернення до часового фактору в якості елементу полістилістики.

Посилюється сприйняття образних сфер в аспекті неокласицизму не тільки шляхом видозмінення стилістики. Це відбувається також за допомогою апеляції до інтонаційного словника минулих епох, використання монограм, цитат, алюзій, колажів тощо. Наприклад, в присвяченому А.Шенбергу Камерному концерті для фортепіано, скрипки та 13 духових А.Берга фігурують три теми, створені із монограм імен і прізвищ діячів нововіденської школи - Арнольд Шенберг (A[rnol]D SCH[on]BE[r]G), Антон Веберн (A[nton w]EBE[rn]) та Альбан Берг (A[1]BA[n] $\mathrm{BE}[\mathrm{r}] \mathrm{G})$. Від самого початку А.Берг хотів назвати частини свого камерного концерту «Дружба», «Кохання» та «Світ», маючи на увазі, відповідно, відносини між А.Шенбергом та його учнями, коханням А.Шенберга до його померлої у 1923 році дружини Матильди та багатоликий i недружній світ по відношенню до нововіденської школи [1]. Тобто в окремих випадках подібна робота 3 музичним матеріалом може стати домінуючим фактором у формуванні не тільки тематизму, а й його семантичної наповненості, що впливає на образну драматургію.

Відомо, що камерна музика головним чином характеризується не тільки відносно невеликою кількістю виконавців [4] [9], але й направленістю на обране кого слухачів. Вже в XIX сторіччі під впливом камерно-інструментальної мініатюри жанр концерту насичується новою образністю, змістовно збагачується ліричністю і психологізмом [8]. Про цю тенденцію, відповідно, можна говорити і у XX сторіччі. Ї̈̈ укорінення та поглиблення формує особливий спосіб висловлювання. Внаслідок цього виникає певний парадокс. 3 однієї сторони, оркестрова музика передбачає об'єднуючу масовість. 3 іншої - камерність як така має драматургічну направленість у бік поглиблення індивідуалізованого та суб'єктивного. Тобто шляхом полярного розмежування типів драматургічних засад відбувається загострення особистісного початку в образних сферах. Наприклад, в Концерті для фортепіано і струнних А.Шнітке домінує сфера монологічно-медитативна, що проявляється в сольних фортепіанних розділах (вступ, каденція, кода), яка значно протиставляється масово-дієвим оркестровим контрастам, музика яких то ущільнюєтсья у кластерну сонорику, то розгалужується у ритмічних геометричних прогресіях.

Характерними є назви творів для солюючих інструментів 3 камерним оркестром. Зазвичай в них авторами закладається певне розуміння природи взаємодії оркестра та сольного інструменту. $\mathcal{C}$ категорія творів, назва яких починається з «Музика для...». Навмисне оминання слова «концерт» свідчить, як правило, про функціональне злиття соліста 3 оркестром, що формує передумови для цілісного сприйняття драматургічного образу. Відбувається це шляхом нівелювання типової змагальності. Інша категорія творів, що починається зі слів «Концерт для...» зазвичай якраз в загальних рисах зберігає цю традицію. Наслідком в цьому випадку стає саме конфліктний тип драматургії. Нерідко у творах XX сторіччя з назвою «Камерна симфонія» фігурує фортепіано в складі оркестру. В таких випадках партія фортепіано асимілюється та втрачає протиставну функцію. Простежується це, наприклад, в Камерній симфонії для 12 
інструментів Д. Енеску, де фортепіано органічно співіснує в загальному музичному просторі без домінуючого драматургічного переходу на перший план.

Окремою рисою камернізації жанру стає мініатюризація у вигляді зменшення тривалості творів. Витримані в естетиці 3 романтичними витоками розгорнуті симфонічні концерти можуть тривати більше години (наприклад, Концерт для фортепіано 3 оркестром Ф.Бузоні), тоді як деякі камерні концерти XX сторіччя можуть зменшуватися до десяти хвилин звучання (наприклад, «...quasi una fantasia...» для фортепіано та двох камерних ансамблів Д.Куртага). Відносно цього можна говорити про щільну образну концентрацію компактних структур. Для творів 3 підкреслено конфліктним типом драматургії прослідковується інтенсифікація розвитку в межах невеликого обсягу композицій. 3 другої сторони, драматургія творів наближених до ліричного складу рухається у бік поглиблення сфери медитативності, споглядання та втримання одного превалюючого образу (наприклад, Концерт для підготовленого фортепіано та камерного оркестру Д.Кейджа 1951р.).

Висновки. Камернізація як тенденція XX сторіччя диктує свої правила драматургічних засад. До головних формотворчих ознак цього явища відносяться такі новації:

- pyx у бік зменшення складу виконавців за двома категоріями - до масової однотембральності та ансамблевої тембрової рясності в контексті формування взаємодії образних сфер;

- жанрові, естетичні прояви неокласичності та полістилістики семантичного становлення образності;

- особливий тип висловлювання спрямований до індивідуалізованого та суб'єктивного початку образних сфер;

- вплив на драматургічні взаємовідносини солюючого інструменту та оркестру в якості асиміляції та розмежування;

- загальна мініатюризація 3 рухом у бік драматургічної інтенсифікації або континуальності превалювання образних сфер.

Відтак формуються нові особливості в усвідомленні концепційної цілісності становлення інтонаційно-образної драматургії.

\section{ЛIТЕРАТУРА}

1. Akopian, L. O. (2010). Muzyka XX veka. Entsyklopedicheskii slovar. [Music of the twentieth century. Encyclopedic dictionary]. Moscow: Praktika [in Russian].

2. Aranovskii M. G. (1979). Simfonicheskiye iskaniia [Symphonic Quest]. Leningrad: Sovetskii kompozitor [in Russian].

3. Basok, M. A. (1983). Sovremennaia kamernaia opera. K probleme spetsyfiki zhanra [Modern chamber opera. To the problem of the genre specifics]. Candidate's thesis. Moscow [in Russian].

4. Keldysh, Y. V. (1974) Muzykalnaia entsyklopediia. Tom 2 [Musical Encyclopedia. Volume 2]. Moscow: Sovetskaya entsyklopediia, Sovetskii kompozitor [in Russian].

5. Povzun, L. I. (2018). Kamernist yak zhanrovo-stylova paradyhma instrumentalno-ansamblevoi tvorchosti [Chamber tendency as genre-style paradigm of instrumental ensemble art]. Doctor's thesis. Odesa [in Ukrainian].

6. Preisman, E. M. (2003). Kamernyi orkestr kak yavlenie v muzykalnoi culture XVII-XX vekov. [Chamber orchestra as a phenomenon in the musical culture of the XVII - XX centuries]. Doctor's thesis. Novosibirsk [in Russian].

7. Riabokonieva, M. O. (2016). Muzychnyi neoklasytsyzm yak fenomen suchasnoi Zakhidno-Yevropeiskoi kultury [Musical neoclasicism as a phenomenon of the current Western-European culture]. Candidate's thesis. Kyiv [in Ukrainian].

8. Savaitan, O. G. (2018). Fortepianna tvorchist M.Regera v konteksti idei mystetstva Avstro-Nimetskoho piznoho romantyzmu [M.Reger's Piano Works in the Context of the Ideas of Austrian-German Paradise Romanticism]. Candidate's thesis. Kyiv [in Ukrainian].

9. Shteinpress, B. S., \& Yampolskii, I. M. (1966) Entsyklopedicheskii muzykalnyi slovar [Encyclopedic musical dictionary]. Moscow: Sovetskaya entsyklopediia [in Russian]. 